available online http://jurnal.um-tapsel.ac.id/index.php/nusantara/index

\title{
GOLPUT TERDIDIK PADA PILKADA TAHUN 2015 DI KABUPATEN SIJUNJUNG
}

\author{
Lindo Karsyah 1), Asrinaldi ${ }^{2)}$, Aidinil Zetra ${ }^{3)}$ \\ 1,2,3) Megister Ilmu Politik, Universitas Andalas, Padang, Indonesia
}

\begin{abstract}
Abstrak
Partisipasi pemilih pada Pilkada Serentak Tahun 2015 di Kabupaten Sijunjung sangat rendah bila dibanding dengan dua Pilkada sebelumnya. Pemilih yang tidak datang ke Tempat Pemunggutan Suara (TPS) adalah mereka yang terdidik, orang yang paham politik dan punya ketertarikan pada pemilu. Orang melek politik mengabsenkan hak konstitusi dalam pemilihan kepala daerah. Alasan orang terdidik tidak ikut mencoblos, ternyata tidak sekadar hanya disebabkan perkara politis dan ideologis, melainkan karena sumbang kurenah (cacat moralitas) pasangan calon dan kompetensi pasangan calon. Pemilih menjadi enggan ikut berpartisipasi mencoblos karena pasangan calon tidak mau membayar utang pada toko bangunan dan kedai kopi. Pemilih patah semangat untuk mengunakan hak pilih disebabkan kemampuan pasangan calon tidak memadai untuk memimpin daerah.
\end{abstract}

Kata kunci : Pemilih Terdidik, Golput Pilkada 2015

*Correspondence Address : lindokarsyah79@gmail.com DOI : 10.31604/jips.v6i2.2019.388-402

(c)2019 Fakultas Keguruan \& Ilmu Pendidikan UM-Tapanuli Selatan 


\section{PENDAHULUAN}

Partisipasi pemilih pada pemilihan kepala daerah merupakan momen penggunaan hak konstitusional warga dalam berdemokrasi. Adnan (2012:12) menegaskan, partisipasi warga dalam menentukan kepala daerah secara langsung merupakan perubahan politik yang prinsipil dalam upaya perluasan implementasi demokrasi di Indonesia sejak tahun 2005. Dimana sebelumnya, pada zaman Orde Baru, rakyat hanya sebagai objek politik belaka, sekarang rakyat menjadi subjek penentu siapa yang akan menjadi kepala daerah.

Kepemilihan rakyat secara langsung pada pemilihan kepala daerah merupakan amanat pasal 18 ayat 4 Undang-Undang Dasar 1945 dan Pasal 56 ayat (1) UU No 32 Tahun 2004 tentang Pemerintah Daerah yang berbunyi; Kepala Daerah dan Wakil Kepala Daerah dipilih dalam satu pasangan calon yang dilaksanakan secara demokratis berdasarkan asas langsung, umum, bebas, rahasia, jujur dan adil.

Demokratis bisa dimaknai demokrasi secara langsung, demokrasi secara perwakilan, atau bahkan secara progresif dapat diartikan disetujui oleh seluruh rakyat secara aklamasi, pun juga cara yang tidak kurang nilai demokratisnya. Negara Indonesia memutuskan pemilihan demokrasi secara langsung untuk pemilihan kepala daerah sebagaimana termaktub dalam pasal 1 ayat 1 UU No. 8 Tahun 2015 tentang pemilihan kepala daerah.

Peraturan di atas jelas telah memberikan hak politik kepada rakyat untuk memilih gubernur dan bupati/walikota. Seiring dengan itu, hak politik masyarakat terbuka lebar untuk melakukan partisipasi politik secara konvensional. Kendati demikian, fakta dari pemilu ke pemilu, banyak warga yang tidak menggunakan hak politik tersebut. Kajian terbaru tentang non voter dilakukan Mujani (2007). Saiful menemukan fakta bahwa semakin tinggi pendidikan orang, makin tidak berminat mereka datang ke Tempat Pemunggutan Suara (TPS). Mereka adalah pemilih rasional dan terdidik, tetapi apatis dan skeptis dengan pemilihan umum. Namun Saiful tidak menguraikan alasan apatisme dan skeptisme para non voter dari kalangan terdidik. Sementara pendalaman penjelasan alasan ketidakmemilihan kalangan melek politik jelas sangat penting dalam keilmuan perilaku pemilih.

Kajian yang sama juga dilakukan Bismar Arianto, dimuat dalam Jurnal 
Ilmu Politik dan Ilmu Pemerintahan tahun 2011. Bismar mengutip pendapat Arbi Sanit dan mengemukan bahwa orang yang tidak memilih disebut dengan golongan putih (golput). Golput muncul sebagai gerakan protes politik karena mereka kecewa terhadap penanganan perkara kebangsaan. Mereka menyampaikan protes itu saat penyelenggaraan pemilu. Bismar juga tidak menjelaskan perkara kebangsaan apa saja yang memicu pemilih jadi golput.

Pada sisi lain, Budiarjo (1996:185) menyatakan dalam negaranegara demokratis umumnya menganggap lebih banyak partisipasi masyarakat, makin lebih baik kualitas demokrasi. Partisipasi masyarakat merupakan implementasi nilai demokrasi dan memiliki peran penting dalam kehidupan politik. Karena dalam negara demokrasi semua bersumber pada rakyat, oleh rakyat, dan untuk rakyat.

Bahkan Verba dan Nie, (1972) menyebut partisipasi politik sebagai cornerstone dan jantung demokrasi. Pendapat tersebut disokong oleh Helander (2012), bahwa partisipasi politik adalah prasyarat utama dalam sebuah negara demokrasi. Di sinilah titik masalah bahwa kualitas kehidupan berdemokrasi ditentukan oleh tingkat penggunaan hak memilih oleh warga negara. Namun dari pemilihan kepala daerah setiap periode di Kabupaten Sijunjung, warga yang tidak menggunakan hak pilihnya terus meningkat. Lebih menarik lagi, sebagaimana hasil penelitian Mujani sebagian yang tidak memilih itu adalah kalangan melek politik. Timbul pertanyaan, apa penyebab orang melek politik tidak menggunakan hak pilihnya.

Tulisan ini mengurai alasanalasan orang melek politik yang tidak memilih dan tidak dalam posisi menegasikan apa yang telah dihasilkan oleh penelitian-penelitian di atas, tetapi akan melanjutkan kajian yang masih menyisakan ruang penelitian. Ada ceruk yang belum terjelaskan oleh kajian sebelumnya, terutama soal pendalaman penjelasan mengapa orang melek politik cendrung tidak memilih. Selain itu, kajian non voter di Kabupaten Sijunjung belum pernah dilakukan dan ditambah lagi animo pemilih dalam menggunakan hak pilihnya sangat rendah. Animo memilih warga Kabupaten Sijunjung jauh lebih rendah dibanding Kabupaten Dhamasraya yang notebene sebagai kabupaten pemekaran dari Kabupaten Sijunjung 
Tabel 1

Partisipasi dan Golput di Kabupaten Sijunjung

\begin{tabular}{|c|c|c|c|c|}
\hline No & Tahun & \multicolumn{2}{|c|}{ Partisipasi } & Golput \\
\cline { 3 - 4 } & Pilkada & Jumlah & $\%$ & \\
\hline 1 & 2005 & 114.375 & $\begin{array}{r}70,95 \\
\text { Persen }\end{array}$ & $\begin{array}{c}29,05 \\
\text { Persen }\end{array}$ \\
\hline 2 & 2010 & 134.980 & $\begin{array}{r}66,98 \\
\text { Persen }\end{array}$ & $\begin{array}{c}33,02 \\
\text { Persen }\end{array}$ \\
\hline 3 & 2015 & 147.946 & $\begin{array}{c}58,93 \\
\text { Persen }\end{array}$ & $\begin{array}{c}41,07 \\
\text { Persen }\end{array}$ \\
\hline
\end{tabular}

Sumber: KPU Kabupaten Sijunjung

Golput dalam tulisan ini dipahami sebagaimana yang diutarakan Arbi Sanit, yaitu; mereka secara sadar yang tidak puas dengan keadaan sekarang, karena aturan main demokrasi diinjak-injak partai politik dan juga tidak berfungsinya lembaga demokrasi (parpol) sebagaimana kehendak rakyat dalam sistem demokrasi. Kemudian, mereka tidak datang ke TPS atau datang ke TPS namun membuat suara tidak sah.

Dengan kata lain, golput adalah pemilih yang dengan sengaja atau dengan maksud dan tujuan yang jelas menolak memberikan suara pada pemilu. Golput tidak hanya sekadar gerakan atau imbauan, melainkan juga tindakan tidak datang atau datang ke
TPS, akan tetapi kedatangannya dihitung sebagai partisipasi namun suaranya tidak sah.

Sementara golput terdidik atau melek politik dimaknai dorongan aktif berupa mencari informasi tentang kebijakan publik di media massa, dokumen anggaran daerah, hingga profil mendalam dari calon yang maju dalam pemilu. Literasi politik dalam konteks pemilu dipahami sebagai kemampuan masyarakat untuk mendefinisikan kebutuhan mereka akan substansi politik terutama perihal pemilu. Mengetahui strategi pencarian informasi apa, siapa, dan mengapa mereka harus memilih? Memiliki kemampuan untuk mengakses informasi seputar kandidat yang akan mewakili mereka nantinya (Setyaningsih: 2014).

\section{METODE PENELITIAN}

Kajian ini menggunakan metode pendekatan kualitatif dengan strategi studi kasus. Ada dua alasan untuk pendekatan ini. Pertama, peneliti ingin mendapatkan kedalaman informasi alasan pemilih melek politik jadi golput sebagai fokus utama daripada agregasi yang bertumpu pada logika matematis, prinsip angka dan metode statistik. Kedua, dengan metode ini diharapkan dapat menangkap alasan-alasan dan 
makna sesungguhnya yang ada dalam pikiran pemilih yang secara sadar tidak menggunakan hak pilihnya.

Penelitian ini terfokus pada orang melek politik tidak memilih pada Pilkada Serentak Tahun 2015 di Kabupaten Sijunjung. Alasan-alasan orang melek politik menjadi golput akan diamati dan dianalisis secara cermat sampai tuntas. Kasus golput akan didalami secara individu-individu dan kemudian dilakukan analisis tajam terkait alasan-alasan yang memicu kegolputan informan.

Studi ini akan melakukan pengujian secara rinci terhadap alasan orang melek politik tidak mengunakan hak pilihnya pada Pilkada Serentak Tahun 2015 di Kabupaten Sijunjung. Kemudian kajian ini secara intensif memusatkan perhatian pada alasan orang paham politik dengan segenap argumen ketidakmemilihannya dalam iven pemilihan kepala daerah serentak pertama di Indonesia. Dari argumen yang disampaikan, peneliti akan berusaha menguji secara mendalam sehingga mendapatkan semua informasi penting.

Penelitian ini memusatkan perhatian pada fenomena golput dari kalangan orang terdidik atau melek politik. Orang terdidik adalah elemen penting bagi tumbuh kembangnya demokrasi di sebuah negara. Lebih penting lagi, walau di Kabupaten Sijunjung penduduknya relatif homogen, namun alasan satu pribadi dengan pribadi lainnya sering tidak sama kenapa mereka tidak mengunakan hak politik dalam pemilu. Fenomena ini tidak bisa generalisasi sehingga perlu kajian studi kasus.

Dalam menentukan informan, penulis mengacu pada teknik "purposive sampling", peneliti memilih informan yang dianggap tahu (key informan) dan dapat dipercaya untuk menjadi sumber data yang mantap dan mengetahui masalahnya secara mendalam. Informan dalam penelitian ini adalah pemilih yang secara administrasi dan defacto berdomisili di Kabupaten Sijunjung. Pemilih dimaksud adalah pemilih yang mewakili orang paham politik dari tingkat pendidikan dan orang paham politik karena otodidak mereka ingin tahu seputar pemilihan kepala daerah.

Sebagai informan awal, peneliti menemukan dua orang pemilih melek politik yang golput. Mereka adalah Noviandi Nafril, pada TPS 2 Nagari Padang Sibusuk, Kecamatan Kupitan dan Yori Warta Ananda dan terdaftar Daftar Pemilih Tetap (DPT) TPS 5 Nagari 
Pematang Panjang, Kecamatan Sijunjung. Mereka akan menjadi informan awal dalam penelitian ini. Selanjutnya akan digunakan teknik snowball dalam menambah jumlah informan. Peneliti akan mengunakan pertanyaan saringan agar kriteria informan tetap terpenuhi.

Selain memakai teknik snowball, peneliti juga menyandingkan formulir C7 KWK Pilkada Sijunjung 2015 dengan DPT TPS per TPS. Dari sandingan itu didapat nama-nama pemilih yang tidak menggunakan hak pilihnya. Setelah itu, peneliti melakukan pemilahan terhadap pemilih yang melek politik dengan koordinasi dengan mantan Panitia Pemunggutan Suara di Nagari TPS tersebut. Ada dua indikator yang ditanyakan kepada PPS, yaitu pendidikan pemilih dan keaktifan dalam diskusi kepemiluan. Indikator di atas sebagaimana konsep Setyaningsih bisa dijadikan rujukan bahwa pemilih tersebut melek politik.

Peneliti menemukan 19 nama informan sebagai data awal. Setelah meneliti ke lapangan, tiga orang mengatakan dengan tegas bahwa mereka datang ke TPS, namun namanya tidak ada dalam C7 KWK Pilkada Sijunjung tahun 2015. Mereka adalah Desvi Ramon, Syamsul Arifin, dan Alfian Toni.
Mereka mencoblos dan masih ingat pasangan mana yang mereka pilih. Mereka mempertanyakan kinerja penyelenggara di tingkat TPS. Tiga pemilih di atas terheran-heran ketika peneliti mengkonfirmasi kegolputan mereka.

Kemudian ada 6 informan termasuk golput politis, dua ideologis, dua teknis dan terakhir ada 6 informan yang menurut peneliti belum terjangkau dalam jenis-jenis golput yang diutarakan sejumlah pakar. Alasan-alasan mereka mengalpakan hak politiknya belum bisa dimasukan ke kategori-kategori yang diuraikan sebelumnya.

\section{HASIL DAN PEMBAHASAN}

\section{Golput Teknis}

Eep Saefullah dalam Efriza (2012:546-547) menjelaskan bahwa golput teknis dikategorikan ke dalam beberapa kelompok. Di antaranya, pemilih yang berhalangan hadir karena ketiduran seusai bergadang semalaman sehingga kehilangan kesempatan mencoblos. Berikutnya, alasan kelelahan, sakit, harus mengurus jenazah dan memakamkan kerabatnya menjadi penyebab absen ke Tempat Pemunggutan Suara. Selain itu, alasan keliru coblos akibat gagalnya sosialisasi 
atau minimnya pengetahuan pemilih. Pemilih yang kurang pengetahuan misalnya di pelosok daerah. Mereka yang tak tahu untuk apa pemilu diadakan dan untuk apa mereka memilih, kaitan pilihan dan kepentingan, bahkan tak tahu apa yang ia inginkan sehingga gamang dan tak mencoblos. Terakhir yang menjadi indikator golput non voter teknis adalah pemilik suara tidak dapat memilih karena tidak mendapat undangan dan tidak terdaftar sebagai pemilih (tidak masuk dalam daftar pemilih tetap) atau disengaja tidak diberikan surat pemberitahuan oleh pihak panitia walaupun sudah terdaftar dalam daftar pemilih tetap. Berdasarkan indikator di atas, peneliti menemukan dua informan yang masuk kategori golput teknis. Mereka adalah Zainal Ahmad dan Ricci Vivi Eka Sanova.

Zainal Ahmad menjadi golput karena sakit. Pada tanggal 9 Desember 2015, dia sedang pergi berobat. Sedangkan Ricci Vivi Eka Sanova, saat hari pemilihan, Ricci sedang ada hajatan baralek atau resepsi keluarga di Kota Solok.

\section{Golput Ideologis}

Golput ideologis punya keyakinan bahwa demokrasi liberal adalah sebuah sistem sesat dan menyesatkan. Merujuk pada pandangan Eep Saefullah dalam Efriza (2012:546-547), Golput ideologis menolak pemilu sebagai jalan memilih pemimpin. Pemilu menyamakan suara orang terdidik dan tidak terdidik. Suara mereka yang paham dan tidak paham sama nilainya. Suara siapa pun tetap dihitung satu.

Tegasnya, menurut pandangan Eep Saefulloh Fatah (dalam Arianto, 2011: 54), golput ideologis merupakan pemilih yang tak percaya pada mekanisme demokrasi (liberal) dan tak mau terlibat di dalamnya entah karena alasan fundamentalisme agama atau alasan politik ideologis lain. Pandangan ini menegaskan bahwa pemilih jadi golput karena dorongan keyakinan yang dianut oleh pemilih itu sendiri. Ideologi yang menyebabkan mereka tidak datang ke TPS. Keyakinan pada gagasan yang menjadi alasan bagi mereka untuk tidak ikut mencoblos.

Dari penelitian peneliti di lapangan, ada dua informan yang masuk kategori golput ideologis. Informan yang dimaksud adalah Sridewi Angraini dan Salni Desi. Dua informan ini sama-sama bergabung pada ormas Hizbut Tahir Indonesia (HTI) ketika menjalani pendidikan di Institut Agama Islam Negeri (IAIN) Imam Bonjol Padang. Mereka juga sama-sama berprofesi 
sebagai guru. Sridewi Angraini tinggal di Nagari Silongo, Kecamatan Lubuk Tarok, semantara Salni Desi berdomisili di Nagari Tanjung Bonai Aur, Kecamatan Sumpur Kudus.

\section{Golput Politis}

Golput politis ini terdiri atas beberapa kelompok, antara lain: Pemilih tidak memiliki pilihan dari salah satu kandidat karena tidak sesuai dengan harapannya sehingga dia tidak mau mencoblos. Sebagaimana diuraikan Eep Saefulloh Fatah (dalam Arianto, 2011: 54), pemilih berkarakter ini lebih memfokuskan penilaian pada kandidat yang sedang bertarung. Mereka membaca, mempelajari dan menilai kepribadian dan kompetensi serta pengalaman sosok yang sedang bersaing merebut kursi kekuasaan. Ketika usaha memahami dan menilai berujung pada kesimpulan bahwa tidak ada satu pun sosok yang bisa diharapkan, saat itulah mereka memutuskan untuk tidak memilih.

Berikutnya, pemilih tidak percaya formalisme sekalipun bersahabat dengan elitisme dan tak percaya formalisme sekaligus elitisme. Biasanya mereka anti terhadap hal-hal formal, seperti partai, pemilu, parlemen, dan pemerintah. Pemilih yang tidak mau memilih karena menganggap demokratisasi sebagai arena permainan elite menggunakan arena dan kendaraan formal. Mereka tidak percaya pemilu dan pilihan mereka membawa perubahan terhadap kehidupan mereka. Dalam bahasa Arbi Sanit (1992:46-47), mereka yang tidak percaya tersebut melakukan gerakan protes politik. Mereka mengugat segenap problem kebangsaan. Sasaran gugatan mereka adalah penyelenggaraan pemilu.

Pendapat yang hampir mirip juga dikemukan Novel Ali (1999:22) tentang non voter politis. Novel Ali menjelaskan golput politis adalah mereka yang tidak bersedia menggunakan hak pilihnya dalam pemilu dikarenakan alasan politik, misalnya tidak puas dengan kualitas partai politik yang ada. Pendapat ini diperjelas lagi oleh Bismar (2011:56). Bismar membedahnya dari dua perspektif, yaitu faktor internal dan eksternal. Faktor eksternal, yaitu ketidakpercayaan dengan partai, tak punya pilihan dari kandidat yang tersedia, stigma politik itu kotor, jahat, menghalalkan segala cara dan para politisi yang tidak mengakar dan mereka lebih dekat dengan para petinggi partai dan pemegang kekuasaan.

Dari paparan teoritis di atas, peneliti menemukan 6 (enam) informan 
yang masuk kategori non voter politis. Mereka adalah Darussalam, Sukarni Malin Permato, Dadang, Sumarnis, Donplis dan Saluhi. Dalam wawancara dengan informan tersebut, alasan dominan yang menyebabkan mereka tidak datang ke TPS karena faktor politis. Di samping itu, juga ada faktor lainnya yang jadi pertimbangan bagi mereka untuk tidak mengunakan hak pilihnya.

\section{Golput Sumbang Perangai (Moralitas) dan Kompetensi Pasangan Calon}

Ada enam informan yang menurut peneliti belum terjangkau dalam jenis-jenis golput yang diutarakan sejumlah pakar. Alasan-alasan mereka mengalpakan hak politiknya belum bisa dimasukan ke kategori-kategori yang diuraikan sebelumnya. Maka dari itu, peneliti akan memasukan ke dalam jenis non voter yang akan menjadi temuan peneliti. Sebelum menamakan alasanalasan yang dikemukan, peneliti akan mengurai lebih dahulu alasan-alasannya tersebut. Informan tersebut adalah Noviandi Nafril, Yori Warta Ananda, Adrial, Asril, Efa Arnizain dan Alam Sari.

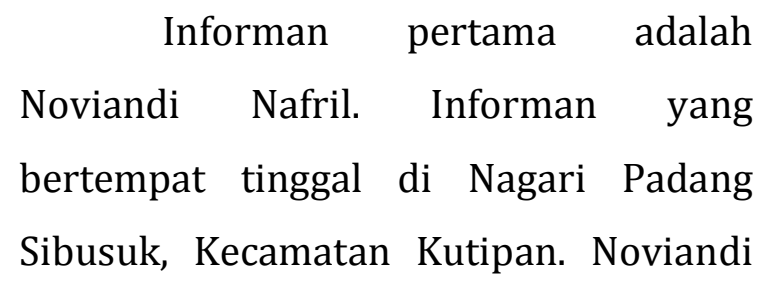

terdata pada TPS 2 Nagari Padang Sibusuk. Informan ini tergolong unik. Dia datang ke TPS, tetapi hanya mencoblos surat suara Gubernur dan Wakil Gubernur Sumatera Barat tahun 2015 dan mengabsenkan hak suaranya pada surat suara Bupati Sijunjung dan Wakil Bupati Sijunjung tahun 2015.

Sebelum menjelaskan sikapnya kepada peneliti, Noviandi menceritakan bahwa dia pernah menjabat sebagai Ketua Bapilu Partai Demokrat Kabupaten Sijunjung tahun 2009 dan mengundurkan diri dari kegiatan kepartaian tahun 2010. Noviandi sering ikut pendidikan dan pelatihan (diklat) kader yang diselenggarakan oleh Partai Demokrat. Diklat dilaksanakan tidak saja di Kota Padang, tetapi juga di Jakarta. Dalam beberapa kesempatan, Noviandi bertemu dengan Susilo Bambang Yudhoyono (SBY) dan petinggi lain berlambang bintang mercy tersebut. Dia tidak hanya jadi peserta biasa, melainkan juga terlibat dalam diskusi dan dialog terbatas dengan para petinggi partai.

Dalam perjalanan kaderisasi, menurut Noviandi, muncullah berbagai karakter kader dan pengurus. Satu di antaranya karakter menghalalkan segala cara dalam mencari kekuasaan dan keuntungan. Mereka tidak lagi mengindahkan nilai-nilai kejujuran. 
Mereka mengabaikan falsafah partai sebagai partai yang lahir di zaman reformasi. Slogan partai melawan korupsi hanya iklan belaka. Intinya kekuasaan dan kepentingan. Untuk mencapai hal demikian, apapun dilakukan. Noviandi mulai terganggu dan melihat partai bukan dunianya. Noviandi merasa asing dan terusik dengan perilaku kader dan pengurus. Karena tidak tahan dengan kondisi yang tidak ideal, Noviandi memutuskan pengunduran diri dari dunia perpolitikan. Dia berhenti jadi kader partai. Sejak itu, Noviandi tidak lagi tertarik bergabung dengan partai.

Informan berikutnya bernama Yori Warta Ananda. Yori terdaftar di TPS 5 Nagari Pematang Panjang, Kecamatan Sijunjung. Yori adalah pemilik Bengkel Anugrah. Bengkel Anugrah merupakan bengkel mobil terbesar di Kabupaten Sijunjung. Yori memutuskan tidak datang ke TPS kendati mamaknya kandungnya juga calon Bupati Sijunjung tahun 2015, Alshelfine. Yori tidak berpartisipasi pada kontestasi saudara ibunya menjadi orang nomor satu di Kabupaten Sijunjung.

Ada sejumlah alasan yang menyebabkan Yori bersikap menjadi golput. Alasan utamanya adalah perkara moral. Mamaknya yang berjuang menjadi Bupati Sijunjung bermasalah moralnya. Moralnya sumbing. Mamaknya itu mengabaikan kewajibannnya pada rakyat kecil. Yori memberi contoh perilaku mamaknya ketika masa belum mulai kampanye Pilkada 2015. Saat itu, Alshelfine berutang pada toko bangunan dan kedai kopi, tetapi mamaknya itu tidak membayarnya.

Sebagai kemenakan, Yori malu dengan perangai mamaknya. Yori malu pada orang yang piutangnya tidak dibayar mamaknya. Pemilik toko bangunan datang ke bengkelnya. Setiap datang, pemilik bengkel itu pasti menanyakan soal utang mamaknya. Pemilik toko itu minta nomor handphone aktif Alshelfine. Yori memberikan nomor yang diminta. Yori baru saja menelepon mamaknya karena itu ia yakin itu nomor yang diberikan adalah nomor mamaknya. Namun ketika pemilik toko menelepon, alangkah terkejutnya Yori dengan jawaban yang didapat dari nomor yang dikontak. Suara dari nomor tersebut mengatakan bahwa salah sambung dan dirinya bukan Alshelfine.

Usai menyampaikan itu, Yori kembali menegaskan bahwa dirinya tidak sekali dua kali didatangi orangorang yang piutangnya tidak dibayar mamaknya. Yori mengaku sanggup 
membayar utang mamaknya, tetapi poinnya bukan di sana. Ini bukan perkara nilai nominal, tetapi nilai moral.

Menurut Yori, perkara utang dengan rakyat kecil mesti diprioritaskan pembayarannya karena menyangkut dengan periuk nasi yang bersangkutan. Hal seperti ini saja tak benar, bagaimana dengan hal-hal yang lain. Alshelfine mengabaikan hak satu dua orang, padahal itu kewajiban keuangannya.

Informan berikutnya bernama Adrial. Adrial tinggal di Nagari Muaro Bodi, Kecamatan IV Nagari. Dari data C7 KWK KPU Kabupaten Sijunjung, Adrial tidak datang ke TPS. Ketika diwawancara, dia juga mengakui bahwa dia tidak memilih pada Pilkada serentak 2015. Pada hari itu, dia juga tidak ingat bahwa dia pergi kemana, tetapi yang jelas dia punya alasan untuk tidak mencoblos.

Disampaikan Adrial kepada peneliti, bahwa dia sudah delapan tahun di kampung. Sebelumnya dia merantau di Jakarta dan bekerja di perusahan Abdul Latif. Banyak kursus manajemen yang diikuti. Sehingga posisi terakhirnya adalah manager. Waktu hampir satu dekade di kampung, membuatnya dia geleng-geleng kepala. Betapa tidak, kata Adrial, di Sijunjung ini banyak pemimpin semu. Pemimpin instan. Kepala daerah tidak punya visi yang jelas dan terukur.

Berikutnya adalah informan bernama Asril. Warga yang terdaftar sebagai pemilih di Nagari Tanjung Bonai Aur, Kecamatan Sumpur Kudus kepada peneliti mengatakan dirinya tahu dengan tiga pasangan calon. Pengetahuannya atas tiga pasangan calon bersumber dari hasil diskusi dan membaca sejumlah brosur yang beredar di masyarakat. Asril tamat STM di Kota Pariaman tahun 1989 dan bekerja sebagai wiraswasta. Dia bergabung dalam Persatuan Keluarga Daerah Piaman (PKDP).

Sosok yang pas memimpin Sijunjung adalah sosok punya kapasitas dan kompetensi yang tidak diragukan. Ia menyebut nama Syafii Maarif yang berkelas demikian. Tokoh nasional asal Sumpur Kudus baru cocok untuk Sijunjung ke depan. Jika tidak tokoh sekaliber intelektual dengan Syafii Maarif, Sijunjung tidak akan mengalami kemajuan. Sijunjung mungkin mundur dan tidak jalan di tempat lagi.

Informan selanjutnya bernama Alam Sari. Pengusaha foto copy dan penjual alat Kantor Tulis di Nagari Muaro Bodi, Kecamatan IV Nagari. Sebagai pemilih berpendidikan sarjana, Alam punya pandangan politik kenapa dirinya golput. Dia menakar ketiga 
pasangan calon yang sedang berkompetisi pada pemilihan 2015 adalah sosok yang tidak memiliki visi kerakyatan. Mereka hanya pasangan calon yang terdorong oleh keinginan dan kepentingan kekuasaan pribadi atau golongan untuk maju dalam persaingan pemilihan.

"Kalau kita lihat visi dan misi mereka yang tertuang dalam persyaratan pencalonan tersebut, aroma iming-imingnya terasa sekali. Rakyat dibujuk dengan janji-janji. Janji yang mengiurkan. Rakyat butuh kepastian. Contoh sederhana saja. Sijunjung terang benderang dan suplai listrik sampai ke nagari-nagari. Jika ini jadi pemikiran pasangan calon, penerangan jalan umum (PJU) akan dilaksanakan," (wawancara dengan Alam Sari tanggal 29 Agustus 2017 di Nagari Muaro Bodi).

Ada lagi kasus yang tidak termaktub dalam visi misi pasangan calon, yaitu pemberantasan korupsi secara nyata dan terukur. Dia punya pengalaman empiris bahwa sebagai pemilik toko jualan ATK, tidak sedikit instansi pemerintah yang datang meminta kwintasi kosong. Kalau tidak kwintasi kosong, yang diminta adalah menaikan harga dari harga semestinya. Jika tidak demikian, minta pembelian fiktif. Seolah-olah barangnya dibeli, nyata tidak.

Informan terakhir bernama Efa Arnizain. Warga yang terdaftar sebagai pemilih di Nagari Muaro Bodi. Efa adalah anak Zainal Ahmad, informan yang masuk kategori golput teknis. Zainal Ahmad juga mantan Kepala KUA di Kecamatan IV Nagari. Selain anak mantan pejabat di kecamatan, Efa juga tamatan sarjana muda salah satu perguruan tinggi negeri di Kota Padang.

"Saya memutuskan tidak mengunakan hak pilihnya pada pemilihan kepala daerah di Kabupaten Sijunjung karena tidak ada yang bisa diharapkan dari segi kemampuan kepemimpinan dari pasangan calon yang sedang bersaing meraih simpati publik tersebut. Mereka agak terlihat pintar dalam menulis visi misi, namun gagap dalam mempercakapkan kepada khalayak ramai. Sepertinya, visi dan misi itu bukan buah pikiran mereka," (wawancara dengan Efa Arnizain tanggal 29 Agustus 2017 di Nagari Muaro Bodi).

Efa membaca visi dan misi mereka sebagai pasangan calon. Bahan itu didapat selain dari mengikuti perdebatan di warung kopi, juga membaca lembaran visi misi pasangan calon. Efa meragukan kemampuan 
pasangan calon dalam memimpin kabupaten yang memiliki 61 nagari tersebut.

Dari enam informan di atas, peneliti menamakan golput moralitas dan kompetensi. Informan menilai pasangan calon lemah secara kemampuan baik secara intelektual dan kepemimpinan untuk duduk sebagai kepala daerah. Berikut tabel di bawah ini:

\begin{tabular}{|c|c|c|c|c|}
\hline $\begin{array}{l}\mathbf{N} \\
\mathbf{o}\end{array}$ & $\begin{array}{c}\text { Nama } \\
\text { Informan }\end{array}$ & $\begin{array}{l}\text { Jenis Non } \\
\text { Voter }\end{array}$ & Alasan & Analisis \\
\hline 1 & $\begin{array}{l}\text { Noviandi } \\
\text { Nafril }\end{array}$ & $\begin{array}{l}\text { Moralitas dan } \\
\text { komptensi }\end{array}$ & $\begin{array}{l}\text {-Moral } \\
\text { pasangan } \\
\text { calon } \\
\text { diragukan } \\
\text {-Kompetensi } \\
\text { pasangan } \\
\text { calon } \\
\text { standard }\end{array}$ & $\begin{array}{l}\text { Masuk } \\
\text { ketagori non } \\
\text { voter } \\
\text { moralitas dan } \\
\text { kompetensi }\end{array}$ \\
\hline 2 & $\begin{array}{l}\text { Yori Warta } \\
\text { Ananda }\end{array}$ & $\begin{array}{l}\text { Moralitas dan } \\
\text { kompetensi }\end{array}$ & $\begin{array}{l}\text {-Kualitas } \\
\text { moral } \\
\text { pasangan } \\
\text { calon } \\
\text { memprihatin } \\
\text { kan - } \\
\text { Kompetensi } \\
\text { pasangan } \\
\text { calon tidak } \\
\text { teruji }\end{array}$ & $\begin{array}{l}\text { Masuk } \\
\text { ketagori non } \\
\text { voter } \\
\text { moralitas dan } \\
\text { kompetensi }\end{array}$ \\
\hline 3 & Alam Sari & $\begin{array}{l}\text { Moralitas dan } \\
\text { Kompetensi }\end{array}$ & $\begin{array}{l}\text {-Tidak peka } \\
\text { dengan } \\
\text { perilaku } \\
\text { korup } \\
\text { birokrat } \\
\text { - Tidak punya } \\
\text { pemikiran } \\
\text { yang } \\
\text { dibutuhkan } \\
\text { Sijunjung }\end{array}$ & $\begin{array}{l}\text { Masuk } \\
\text { ketagori non } \\
\text { voter } \\
\text { moralitas dan } \\
\text { kompetensi }\end{array}$ \\
\hline 4 & Adrial & Kompetensi & $\begin{array}{l}\text { Kompetensi } \\
\text { pasangan } \\
\text { calon tidak } \\
\text { memadai }\end{array}$ & $\begin{array}{l}\text { Non voter } \\
\text { kompetensi }\end{array}$ \\
\hline 5 & Asril & Kompetensi & $\begin{array}{l}\text { Kompetensi } \\
\text { calon tidak } \\
\text { sekelas buya } \\
\text { Syafii Maarif }\end{array}$ & $\begin{array}{l}\text { Non voter } \\
\text { kompetensi }\end{array}$ \\
\hline 6 & $\begin{array}{l}\text { Efa } \\
\text { Arnizain }\end{array}$ & Kompetensi & $\begin{array}{l}\text { Naskah visi } \\
\text { misi bagus, } \\
\text { namun gagap } \\
\text { dalam } \\
\text { mempercaka } \\
\text { pkan ke } \\
\text { publik }\end{array}$ & $\begin{array}{l}\text { Non Voter } \\
\text { kompetensi }\end{array}$ \\
\hline
\end{tabular}

\section{KESIMPULAN}

Seperti diuraikan di awal bahwa tujuan penelitian ini untuk mengetahui alasan-alasan pemilih terdidik menjadi golput pada Pilkada 2015 di Kabupaten Sijunjung. Pemilih melek politik, namun mereka memutuskan untuk tidak mengunakan hak suaranya pada pemilihan Bupati dan Wakil Bupati Sijunjung tahun 2015. Mereka memilih untuk tidak datang ke tempat pemunggutan suara. Mereka menempatkan diri menjadi golongan yang tidak datang ke tempat pemunggutan suara dengan didasarkan atas pertimbangan yang matang. Mereka membaca seluruh bahan kampanye dan sosialisasi tentang pasangan calon. Selain itu, mereka juga mendiskusikan dengan teman-teman mereka tentang dinamika dan rekam jejak pasangan calon.

Dari semua penelusuran itu, mereka baru mengambil sikap untuk menjadi golput. Ketidakmemilihan mereka didasarkan atas dua alasan, yaitu pertama defisit moral pasangan calon dan terakhir kompetensi pasangan calon yang rendah. Pemilih paham politik menimbang moralitas pasangan calon. Mereka mengukur kualitas kepribadian pasangan calon sebagai kandidat kepala daerah. Poin defisit 
moral menjadi hal penting bagi pemilih melek politik untuk memilih atau tidak memilih. Kalau pasangan calon dinilai bermoral, mereka ikut mencoblos. Sebaliknya, mereka menilai pasangan calon tidak bermoral, mereka akan golput.

$$
\text { Dari kajian ini, peneliti }
$$
menenemukan bahwa yang dimaksud defisit moral pasangan calon oleh informan adalah pasangan calon tidak mau membayar utang pada masyarakat dan tidak peka terhadap fenomena korupsi.

Berikutnya, pemilih melek politik juga mempelajari kompetensi pasangan calon. Kompetensi menjadi perhatian pemilih terdidik dalam mengambil sikap politik dalam pemilihan kepala daerah. Mereka mengukur kemampuan calon dalam memimpin daerah. Ukuran mereka mulai dari mempelajari rekam pendidikan pasangan calon dan sampai pada riwayat pekerjaan serta reputasi yang dicapai. Semua itu, mereka nilai dan putuskan sebagai dasar menjadi golput atau tidak. Penelitian ini menemukan bahwa kompetensi pasangan calon adalah ketidakmampuan memimpin daerah, tidak pandai membuat ikon kabupaten, dan visi dan misi tidak realistis.

\section{Daftar Pustaka}

Afrizal. 2008, Pengantar Metode Penelitan Kualitatif: Dari Pengertian Sampai PenelitianLaporan, Padang: Laboratorium Sosiologi FISIP Unand.

Ananta, Aris. Nurvidya Arifin, Evi. Suryadinata, Leo. 2004, Indonesian Electoral Behaviour: A statistical Perspectif, Population Series No. 7, Singapore: The Institute of Southeast Asian Studies.

Arianto, Bismar, 2011, "Analisis Penyebab Masyarakat Tidak Memilih dalam Pemilu."Jurnal Ilmu Politik dan Ilmu Pemerintahan,1(1).http://fisip.umrah. ac.id

Budiardjo, Miriam. 2008, Dasar-Dasar Ilmu Politik, Jakarta: PT. Pustaka Gramedia.

Bungin, Burhan. 2003, Metodologi Penelitian Kualitatif: Aktualisasi Metodologis ke Arah Ragam Varian Kotemporer, Jakarta: Rajawali press.

Caplan, Bryan. 2007, The Myth of Rational Voter: Why Democraties Choose Bad Policies, Princenton University.

Eep Saefulloh Fatah, "Analisis Politik : Mengelola Golput Jakarta", 21 Pebruari 2008 Haryanto, November 1999, "Kebangkitan Party ID: Analisis Perilaku Memilih dalam Politik Lokal di Indonesia." Jurnal Sospol Fisipol UGM.

3).http://jurnalsospol.fisipol.ugm.ac.id

Hendrik, Doni, 2010, "Variabel-variabel yang Mempengaruhi Rendahnnya Partisipasi Politik Masyarakat dalam Pilkada Walikota dan Wakil Walikota Padang Tahun 2008."Jurnal Demokrasi. IX http://ejournal.unp.ac.id.

Iskandar. 2008. Metodologi Peneliti Pendidikan dan Sosial. Jakarta : Gaung Persada Press.

Moleong, J Lexi. 2005, Metodologi Penelitian Kualitatif, Edisi Revisi Bandung:Remaja Rosda Karya. 
Mujani, Syaiful. 2007, Preferensi dan Peta Dukungan Pemilih pada Partai Politik, Kajian BuIanan LSI Edisi 06 Oktober 2007.

Nyarwi, Maret 2014 (207-314), “Golput Pasca Orde Baru: Merekonstruksi UlangDua Perspektif".Jurnal Sospol Fisipol UGM.12: 207314.http ://jurnalsospol.fisipol.ugm.ac.id.

Prihatmoko, J Joko. 2005. Pemilihan Kepala Daerah Langsung: Filosofi, Sistem dan Problema Penerapannya di Indonesia. Yogyakarta: Pustaka Pelajar.

Ramdansyah. 2010. Sisi Gelap Pemilu 2009: Potret Aksesori Demokrasi Indonesia. Jakarta:Rumah Demokrasi.

Ramlan Subakti, Memahami Ilmu Politik, (Jakarta: PT. Gramedia, 1999), 176. Lihat juga Limas Sutanto, Memilih Pemimpin Transisional, dalam Siapa Mau Jadi Presiden, (Jakarta: Buku Kompas, 2004), 14.

Sugiyono. 2009. Metode Penelitian Kuantitatif, Kualitatif, dan R\&D. Bandung Alfabeta.

Suharsimi Arikuntu. 2006. Prosedur Penelitian Suatu Pendekatan Praktik. Jakarta: Rineka Cipta.

Setianto, W.A, Maret 2009, "Kajian Epistemologis Iklan Politik dan Perilaku Memilih dalam Dinamika Pemilu 2009". Jurnal Sospol Fisipol UGM. 12 (3), (257-390).

Santoso,Purwo, November 1999, "Kemandirian Lokal: Pemberdayaan Hak-hak Sipil." Jurnal Sospol Fisipol UGM.3 (2). http://jurnalsospol.fisipol.ugm.ac.id.

Sri Yanuarti, 2009, "Golput dan Pemilu di Indonesia." Jurnal Penelitian Politik LIPI. 6 (1). http:// http://ejournal.politik.lipi.go.id

Yusuf, I.A, Maret 2011, "Media Lokal dalam Konstelasi Komunikasi Politik di Daerah." Jurnal Sospol Fisipol UGM. $14(3)$. http://jurnalsospol.fisipol.ugm.ac.id. 